Bojan Branovački

UDK 159.923.072

Selka Sadiković

DOI: $10.19090 / \mathrm{gff} .2018 .1 .253-269$

Milan Oljača*

Filozofski fakultet

Univerzitet u Novom Sadu

\title{
RELACIJE IZMEĐU VAŽNIH ŽIVOTNIH DOGAĐAJA, OSOBINA LIČNOSTI I ZADOVOLJSTVA ŽIVOTOM
}

Osnovni cilj ovog istraživanja jeste ispitivanje relacija između važnih pozitivnih i negativnih životnih događaja, sa jedne, i osobina ličnosti i zadovoljstva životom, sa druge strane. U istraživanju je učestvovalo 933 ispitanika (50.1\% ženskog pola), starosti od 18 do 69 godina. Primenjena su tri upitnika: UVŽD - namenjen proceni važnih pozitivnih i negativnih životnih događaja, IPIP BFI - namenjen proceni pet bazičnih dimenzija ličnosti: ekstraverzija, prijatnost, savesnost, emocionalna stabilnost i intelekt i upitnik SWLS namenjen proceni kognitivne komponente subjektivnog blagostanja/zadovoljstva životom. Važni negativni životni događaji ostvaruju značajne relacije sa dimenzijom prijatnost, u pozitivnom smeru, kao i sa emocionalnom stabilnošću i zadovoljstvom životom, u negativnom smeru. Važni pozitivni životni događaji ostvaruju značajne relacije sa obrazovanjem, zadovoljstvom životom i dimenzijama prijatnost, ekstraverzija i savesnost, u pozitivnom smeru, kao i sa polom, u negativnom smeru. Rezultati ovog istraživanja daju potvrdu nalazima većine prethodnih istraživanja, ali takođe ukazuju i na potrebu za detaljnijim ispitivanjem relacija između navedenih fenomena.

Ključne reči: životni događaji, osobine ličnosti, zadovoljstvo životom, upitnik važnih životnih događaja

\section{UVOD}

Relacije između osobina ličnosti $i$ životnih događaja

Ključni životni događaji predstavljaju neke od najvažnijih momenata $\mathrm{u}$ životima ljudi. Na primer, brak, preseljenje, rođenje deteta ili smrt bliske osobe mogu promeniti dalji životni tok osobe. Rezultati ranijih studija ukazuju na zaključak da važni životni događaji mogu imati posledice kako na mentalno tako i na fizičko zdravlje (Cleland, Kearns, Tannahill, \& Ellaway, 2016). Sa druge strane,

*milanoljaca@ff.uns.ac.rs 
rezultati pojedinih studija sugerišu da relativno stabilne karakteristike, poput osobina ličnosti i zadovoljstva životom, mogu biti povezane sa učestalošću određenih životnih događaja (Magnus, Diener, Fujita, \& Pavot, 1993; Luhmann, Lucas, Eid, \&amp; Diener, 2013), tj. ukazuju na to da se važni životni događaji ne dešavaju nasumično. Ipak, ove tvrdnje nisu dovoljno istražene. S obzirom na to da važni životni događaji mogu imati značajne posledice na funkcionisanje osobe, veoma je važno podrobnije razumeti odnose koje ovaj fenomen ima sa stabilnim odlikama ljudskog funkcionisanja.

Kako su osobine ličnosti relativno stabilni obrasci kognicija, emocija i ponašanja, one mogu biti povezane sa načinom na koji osobe percipiraju i interpretiraju dešavanja u okruženju, ali i sa iskustvima koja individue doživljavaju. Najčešće ispitivane dimenzije ličnosti, kao potencijalni prediktori životnih događaja, jesu ekstraverzija i neuroticizam (Fergusson \& Horwood, 1987; Headey \& Wearing, 1989; Gomez et al., 2009; Magnus et al., 1993). Nalazi dosadašnjih studija dosledno pokazuju da neuroticizam ostvaruje značajnu pozitivnu povezanost sa negativnim životnim iskustvima, dok ekstraverzija ostvaruje značajnu pozitivnu povezanost sa pozitivnim životnim događajima (Fergusson \& Horwood, 1987; Headey \& Wearing, 1989; Magnus et al., 1993; Gomez et al., 2009; Kandler, Bleidorn, Riemann, Angleitner, \& Spinath, 2012). Značajan je i nalaz da neuroticizam nije povezan sa frekvencijom doživljavanja pozitivnih, kao ni ekstraverzija sa frekvencijom doživljavanja negativnih događaja (Kandler et al., 2012). Povezanost životnih događaja sa dimenzijom otvorenosti prema iskustvu ispitivana je u manjem broju studija (npr. Headey \& Wearing, 1989; Gomez et al., 2009; Kandler et al., 2012), ali nalazi nisu konzistentni. U jednom istraživanju dimenzija otvorenost ostvarila je značajnu relaciju sa pozitivnim događajima, a u druga dva istraživanja i sa pozitivnim i sa negativnim događajima. Pregledom literature pronađena su dva istraživanja koje ispituju povezanosti savesnosti i prijatnosti sa pozitivnim i negativnim životnim događajima (Gomez et al., 2009; Kandler et al., 2012). Savesnost ni u jednom slučaju nije bila značajan prediktor, dok je prijatnost samo u jednom slučaju imala značajnu vezu negativnog usmerenja sa negativnim događajima. Sve povezanosti dobijene u predstavljenim studijama niskog su do umerenog intenziteta. Relativno je malo studija koje ispituju odnos između osobina ličnosti i važnih životnih događaja. Ova studija predstavlja doprinos relativno ograničenom znanju o odnosu ovih konstrukata. 
Relacije između životnih događaja i zadovoljstva životom i osobinama ličnosti

Pretpostavka o značajnoj povezanosti zadovoljstva životom i važnih životnih događaja zasniva se na teoriji stabilnog nivoa subjektivnog blagostanja (eng. set-point theory) (Diener, Lucas, \& Scollon, 2006). Savremene revizije ove teorije (Lybomirsky, Sheldon, \& Schkade, 2005) ukazuju na to da je subjektivno blagostanje relativno stabilno tokom života, a ovaj nalaz se dobijao i u ranijim istraživanjima (Headey \& Wearing, 1989; Lykken \& Tellegen, 1996). Istraživanja dosledno pokazuju da osobe koje su zadovoljnije svojim životom bolje funkcionišu u domenu posla, ljubavnih veza i ličnih odnosa, kao i da poseduju veće sposobnosti razvijanja socijalnih odnosa, te da su ove osobe socijalno aktivnije (npr. Lyubomirsky, King, \& Diener, 2005). Ovo posledično dovodi do toga da u sferi socijalnih odnosa zadovoljne osobe češće doživljavaju značajne pozitivne događaje, poput stupanja u ozbiljnu emocionalnu vezu ili brak, a manje negativnih događaja, vezanih za prekide ili narušavanje bliskih odnosa. Ova pretpostavka u skladu je sa rezultatima istraživanja Lumanove i saradnika (Luhmann, Lucas, Eid, \& Diener, 2013), čiji rezultati ukazuju na to da postoji uticaj nivoa zadovoljstva životom na veliki broj životnih događaja.

Da bi se adekvatno interpretirao odnos između navedenih fenomena, važno je uzeti u obzir kako su i na koji način povezane osobine ličnosti sa zadovoljstvom životom. Istraživanja pokazuju (npr. Steel, Schmidt, \& Shultz, 2008) da povezanosti najjačeg intenzita sa procenom zadovoljstva životom ostvaruju ekstraverzija (prosečna korelacija $r=.28$ ) i neuroticizam (prosečna korelacija $r=-.38$ ). Upravo su ove osobine one za koje autori veruju da u najvećoj meri definišu stabilnu komponentu subjektivnog blagostanja (Lybomirsky et al., 2005). Sa druge strane, nalazi ranijih istraživanja dosledno ukazuju na zaključak da neuroticizam i ekstraverzija ostvaruju sličan obrazac relacija i sa životnim događajima (npr. Gomez et al., 2009; Kandler et al., 2012). Kako bi se podrobnije razumeo složen odnos između ovih fenomena, važno je ispitati prirodu ovih relacija u situaciji kada se osobine ličnosti i zadovoljstvo životom istovremeno posmatraju kao prediktori važnih životnih događaja.

\section{Cilj istraživanja}

Ciljevi ovog rada su ispitivanje relacija između dimenzija ličnosti modela Velikih pet i zadovoljstva životom sa važnim pozitivnim i negativnim životnim događajima. Na osnovu pregleda literature moguće je postaviti nekoliko hipoteza. Očekuje se da neuroticizam značajno predviđa negativne događaje, ali da nije 
značajan prediktor pozitivnih događaja. Drugo, očekuje se da ekstraverzija značajno predviđa pozitivne događaje, ali da nije značajan prediktor negativnih događaja. Eksplorativno će biti ispitani odnosi dimenzija otvorenost, prijatnost i savesnost sa životnim događajima, usled nekonzistentnih nalaza prethodnih istraživanja. Drugi eksplorativni cilj ovog rada jeste ispitati da li zadovoljstvo životom ostvaruje značajne relacije sa važnim životnim događajima, kada su kontroliše efekat relacija bazičnih osobina ličnosti sa važnim životnim događajima. Očekuje se da će zadovoljstvo životom biti značajan prediktor obe vrste životnih događaja.

\section{METOD}

\section{Uzorak i procedura}

U istraživanju je učestvovalo 933 ispitanika ( $50.1 \%$ ženskog pola). Starost ispitanika se kretala u rasponu od 18 do 69 godina $(\mathrm{AS}=34.95, \mathrm{SD}=12.87$ ). Najveći broj ispitanika ima završen fakultet (32.6\%) ili srednju školu (25.6\%), nešto manji broj ispitanika jesu studenti (22.7\%) ili su završili višu/visoku školu (14.9\%), dok je najmanje ispitanika sa završenom osnovnom školom (4.2\%).

Podaci su prikupljeni tokom juna 2017. godine na teritoriji Republike Srbije. Anketa je bila anonimna i na dobrovoljnoj bazi, a ispitanici su potpisali saglasnost o svom učešću u istraživanju.. Baterija testova je distribuirana u papirolovka formatu a za njeno popunjavanje bilo je potrebno odvojiti 30 do 40 minuta.

\section{Instrumenti}

Upitnik važnih životnih događaja (UVŽD: Branovački, Sadiković i Oljača, 2017). Konstrukciji upitnika UVŽD prethodilo je pilot istraživanje u kojem je učestvovalo 188 ispitanika opšte populacije, starosti od 19 do 69 godina. Zadatak ispitanika bio je da navedu 10 do 20 važnih životnih događaja koji su imali veliki uticaj na njihovu životnu putanju. Nakon redukcije početnog seta odgovora (isključivanje sintaksičkih duplikata i semantički sličnih događaja), konstruisana je preliminarna verzija upitnika UVŽD koja se sastojala od 91 događaja. Redukciju početnog seta odgovora sprovela su četiri eksperta iz oblasti individualnih razlika.

Preliminarna verzija upitnika UVŽD zadata je ispitanicima u ovom istraživanju. Zadatak ispitanika bio je da za svaki događaj navedu da li su doživeli taj događaj $(0=$ ne i $1=$ da) kao i da procene valencu događaja, ukoliko su ga doživeli $(-2=$ veoma negativan, $-1=$ negativan, $0=$ neutralan, $1=$ pozitivan i $2=$ veoma pozitivan). U skladu sa dominantnom podelom životnih događaja na 
pozitivne i negativne (Spinhoven, Elzinga, Hovens, Roelofs, Penninx, 2011; Farmer \& Kashdan, 2012; Garcia \& Sikstrom, 2013; Jeronimus, Ormel, Aleman, Penninx \& Riese, 2013; Alea, Ali \& Marcano, 2014) u konačnu verziju upitnika uključeni su samo događaji koji se mogu jasno klasifikovati kao pozitivni (AS valence događaja $>0.50$ ) ili negativni (AS valence događaja $<-0.50$ ). Primenom navedenog kriterijuma isključen je 31 događaj.

Skala važnih pozitivnih životnih događaja (VPŽD) obuhvata 30 pozitivnih događaja iz različitih životnih domena: ličnog, obrazovnog, poslovnog, porodičnog, zdravstvenog i rekreativnog. Pouzdanost skale je prihvatljivo visoka $(\alpha=.76)$. Skala važnih negativnih životnih događaja (VNŽD) obuhvata 30 negativnih događaja iz različitih životnih domena: materijalnog, partnerskog, emocionalnog, zdravstvenog, poslovnog i egzistencijalnog. Pouzdanost skale je visoka $(\alpha=.81)$. Korelacija između dve skale životnih događaja umerena je i pozitivna $(r=.39, p<$ .01). U skladu sa dominantno primenjivanim kriterijumom za formiranje skorova na skalama životnih događaja (npr. Kandler et al., 2012) sumacioni skorovi formirani su tako što su sabrani odgovori ispitanika da li su doživeli određeni događaj (DA 1; NE - 0). Navedena procedura primenjena je za obe skale važnih životnih događaja.

IPIP simulacija upitnika BFI (Big Five Inventory - BFI: Goldberg, 1999). Upitnik je namenjen proceni pet bazičnih osobina ličnosti: ekstraverzija $(\alpha=.80)$, emocionalna stabilnost $(\alpha=.88)$, intelekt $(\alpha=.77)$, savesnost $(\alpha=.81)$ i prijatnost $(\alpha=.77)$. Sastoji se od 50 stavki sa petostepenim formatom odgovora Likertovog tipa. Svaku dimenziju čini 10 stavki.

Skala zadovoljstva životom (Satisfaction with life scale - SWLS: Diener, Emmons, Larsen, \& Griffin, 1985). Skala je namenjena proceni kognitivne komponente subjektivnog blagostanja. Sastoji se od pet stavki sa sedmostepenim formatom odgovora Likertovog tipa $(1=\mathrm{u}$ potpunosti se ne slažem do $7=\mathrm{u}$ potpunosti se slažem). Pouzdanost skale iznosi $\alpha=.83$.

\section{REZULTATI}

Deskriptivni statistički parametri kao i koeficijenti pouzdanosti i korelacija predstavljeni su Tabelom 1. Kako se vrednosti spljoštenosti i zakošenosti kreću u preporučenom opsegu ( \pm 1.5 ; Tabachnick \& Fidell, 2013), zaključeno je da se podaci normalno distribuiraju. Pouzdanosti svih dimenzija i skala primenjenih upitnika kreću se u rasponu od prihvatljivih do veoma dobrih $(.76$ - .88). Sve značajne korelacije niskog su intenziteta u odnosu na kriterijume za interpretaciju visine koeficijenta korelacije koje predlaže Mukaka (2012). Značajnost, intenzitet i 
smer korelacija u skladu su sa teorijskim očekivanjima, sa izuzetkom niske, pozitivne i značajne relacije između dimenzije emocionalna stabilnosti i skale pozitivnih važnih životnih događaja, koja nije očekivana.

S obzirom na to da pol i drugi sociodemografski pokazatelji mogu biti povezani sa prevalencom životnih događaja u određenim životnim razdobljima (npr. Leist, Ferring, \& Filipp, 2010; Vázquez, Panadero, \& Martín, 2015), u analizu su uključene varijable pol i edukativni status kako bi se kontrolisao njihov efekat na relacije između preostalih fenomena. Kako bi se ispitale relacije kontrolnih varijabli, osobina ličnosti i zadovoljstva životom sa pozitivnim i negativnim važnim životnim događajima, primenjene su dve hijerarhijske regresione analize. Kriterijumske varijable predstavljaju pozitivni i negativni važni životni događaji, i to u svakoj analizi po jedni. U prvom koraku modela prediktorske varijable su pol i obrazovanje. U drugom koraku uvode se i osobine ličnosti kao prediktori, dok se u trećem koraku kao prediktor uvodi i zadovoljstvo životom.

Rezultati za prvi model, u kojem su negativni važni životni događaji kriterijumska varijabla, predstavljeni su U Tabeli 2. Sva tri koraka modela statistički su značajna $(\mathrm{p}<.01)$. Prvim korakom modela objašnjeno je $1.5 \%$ varijanse kriterijumske varijable. Drugim korakom modela objašnjeno je dodatnih $3.8 \%$, odnosno $5.3 \%$ varijanse. Trećim korakom modela objašnjeno je dodatnih $7.7 \%$, odnosno $13 \%$ varijanse kriterijumske varijable.

Obe kontrolne varijable izdvajaju se kao značajni prediktori u prvom koraku modela. Uvođenjem osobina ličnosti kao prediktora u drugom koraku modela obrazovanje ostaje značajan prediktor, a značajni prediktori su takođe i prijatnost i emocionalna stabilnost. Uvođenjem zadovoljstva životom kao prediktora u trećem koraku modela obrazovanje više nije značajan prediktor, dok prijatnost u pozitivnom smeru i emocionalna stabilnost u negativnom smeru ostaju značajni prediktori. Zadovoljstvo životom je takođe značajan i najbolji prediktor, u negativnom smeru.

Rezultati za drugi model, u kojem su pozitivni važni životni događaji kriterijumska varijabla, predstavljeni su u Tabeli 4. Sva tri koraka modela statistički su značajna $(p<.01)$. Prvim korakom modela objašnjeno je $0.9 \%$ varijanse kriterijumske varijable. Drugim korakom modela objašnjeno je dodatnih 14.3\%, odnosno $14.8 \%$ varijanse. Trećim korakom modela objašnjeno je dodatnih $0.3 \%$, odnosno $15.1 \%$ varijanse kriterijumske varijable. 


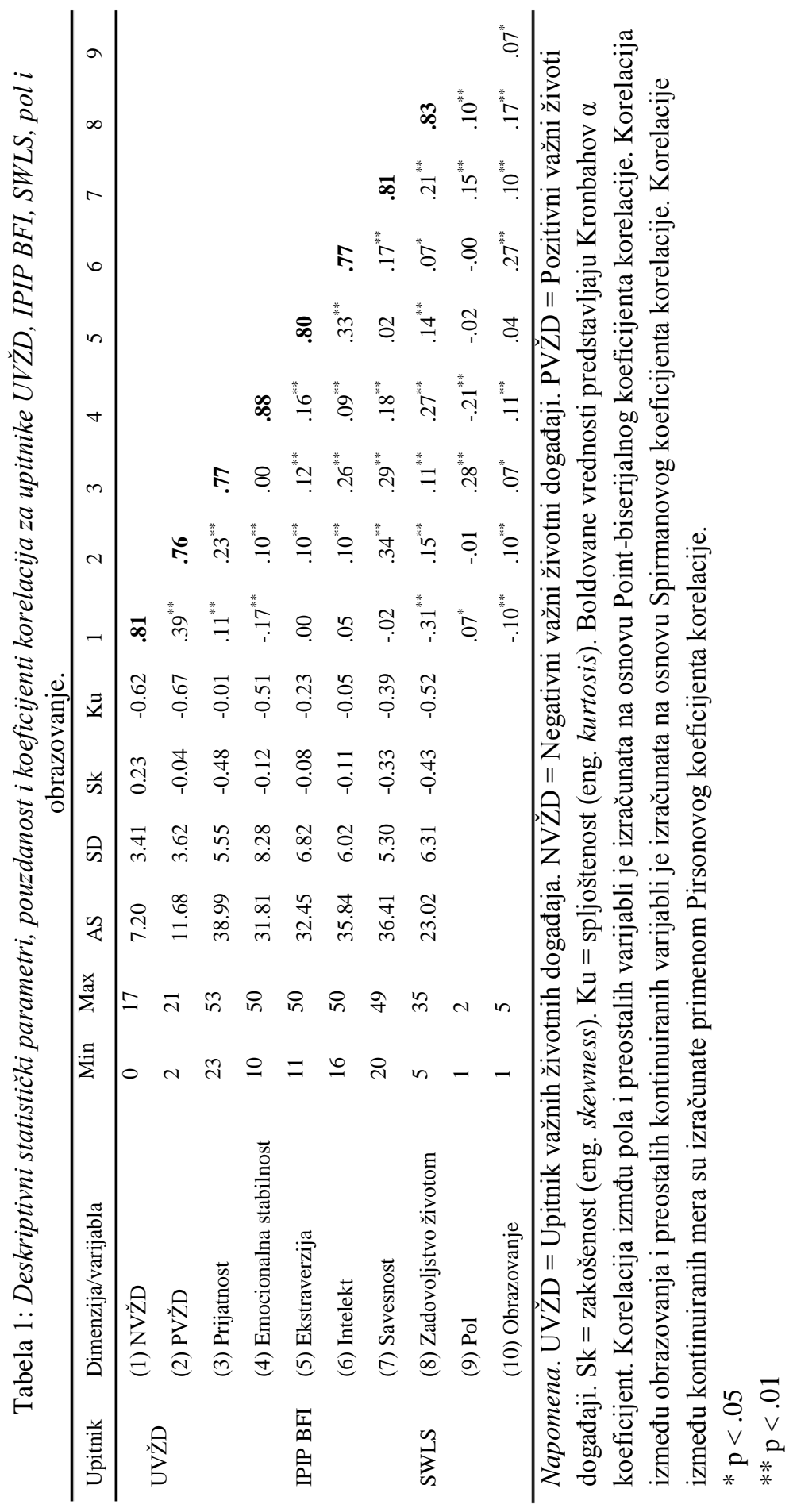


Годишњак Филозофског факултета у Новом Саду, Кюига XLIII-1 (2018) Annual Review of the Faculty of Philosophy, Novi Sad, Volume XLIII-1 (2018)

Tabela 2: Značajnost koraka modela za Negativne važne životne događaje.

\begin{tabular}{lcccccccc}
\hline Korak & $\mathrm{F}-$ test & $\mathrm{DF}$ & $\mathrm{p}$ nivo & $\mathrm{R}$ & $\mathrm{R}^{2}$ & $\Delta \mathrm{R}^{2}$ & $\Delta \mathrm{F}-$ test & $\Delta \mathrm{p}$ nivo \\
\hline 1 & 6.95 & $930 / 2$ & .001 & .121 & .015 & - & 6.95 & .001 \\
2 & 7.34 & $925 / 7$ & .000 & .229 & .053 & .038 & 7.40 & .000 \\
3 & 17.25 & $924 / 8$ & .000 & .361 & .130 & .077 & 82.13 & .000 \\
\hline
\end{tabular}

Napomena. $\Delta \mathrm{R}^{2}$ - promena $\mathrm{R}^{2}$ koeficijenta sa uvođenjem novih prediktora $\mathrm{u}$ narednom koraku modela. $\Delta \mathrm{F}$ - test - vrednost $\mathrm{F}$ - testa za promenu $\mathrm{R}^{2}$ koeficijenta. $\Delta \mathrm{p}$ nivo $-\mathrm{p}$ nivo za za promenu $\mathrm{R}^{2}$ koeficijenta.

Tabela 3: Parcijalni doprinos prediktora u odnosu za skalu Negativnih životnih događaja.

\begin{tabular}{|c|c|c|c|c|}
\hline Korak & Prediktor & $\beta$ & $\mathrm{t}-$ test & $\mathrm{p}$ \\
\hline \multirow{2}{*}{1} & Pol & .075 & 2.30 & .022 \\
\hline & Obrazovanje & -.101 & -3.09 & .002 \\
\hline \multirow{7}{*}{2} & Pol & .016 & 0.47 & .638 \\
\hline & Obrazovanje & -.103 & -3.06 & .002 \\
\hline & Prijatnost & .107 & 3.01 & .003 \\
\hline & Emocionalna stabilnost & -.154 & -4.51 & .000 \\
\hline & Ekstraverzija & -.003 & -0.09 & .928 \\
\hline & Intelekt & .068 & 1.85 & .064 \\
\hline & Savesnost & -.026 & -0.75 & .451 \\
\hline \multirow{8}{*}{3} & Pol & .050 & 1.50 & .134 \\
\hline & Obrazovanje & -.063 & -1.93 & .054 \\
\hline & Prijatnost & .116 & 3.39 & .001 \\
\hline & Emocionalna stabilnost & -.081 & -2.41 & .016 \\
\hline & Ekstraverzija & .029 & 0.88 & .378 \\
\hline & Intelekt & .051 & 1.46 & .143 \\
\hline & Savesnost & .015 & 0.44 & .663 \\
\hline & Zadovoljstvo životom & -.300 & -9.06 & .000 \\
\hline
\end{tabular}

Napomena. Muški pol je kodiran sa „1”, dok je ženski pol kodiran sa „2”. 
Tabela 4: Značajnost koraka modela za pozitivne važne životne događaje.

\begin{tabular}{rrrrcccrr}
\hline Korak & $\mathrm{F}-$ test & \multicolumn{1}{c}{$\mathrm{DF}$} & $\mathrm{p}$ nivo & $\mathrm{R}$ & $\mathrm{R}^{2}$ & $\Delta \mathrm{R}^{2}$ & $\Delta \mathrm{F}-$ test & $\Delta \mathrm{p}$ nivo \\
\hline 1 & 5.20 & $930 / 2$ & .006 & .105 & .009 & - & 5.21 & .006 \\
2 & 24.05 & $925 / 7$ & .000 & .392 & .148 & .143 & 31.24 & .000 \\
3 & 21.64 & $924 / 8$ & .000 & .397 & .151 & .004 & 4.22 & .040 \\
\hline
\end{tabular}

Kao značajan prediktor u prvom koraku modela izdvaja se obrazovanje. Uvođenjem osobina ličnosti kao prediktora u drugom koraku modela obrazovanje ostaje značajan prediktor, ali značajan prediktor postaje i pol, kao i prijatnost, savesnost. Uvođenjem zadovoljstva životom kao prediktora u trećem koraku modela svi značajni prediktori iz drugog koraka modela ostaju značajni i u trećem koraku modela, dok je zadovoljstvo životom takođe značajan prediktor.

Tabela 5: Parcijalni doprinos prediktora u odnosu za skalu Pozitivnih životnih događaja.

\begin{tabular}{rlrrr}
\hline Korak & \multicolumn{1}{c}{ Prediktor } & \multicolumn{1}{l}{$\mathrm{B}$} & $\mathrm{t}-$ test & $\mathrm{p}$ \\
\hline \multirow{2}{*}{1} & Pol & -.017 & -.535 & .593 \\
& Obrazovanje & .105 & 3.211 & $\mathbf{. 0 0 1}$ \\
& & & & \\
& Pol & -.102 & -3.110 & $\mathbf{. 0 0 2}$ \\
& Obrazovanje & .077 & 2.420 & $\mathbf{. 0 1 6}$ \\
& Prijatnost & .165 & 4.893 & $\mathbf{. 0 0 0}$ \\
& Emocionalna stabilnost & .010 & .324 & .746 \\
& Ekstraverzija & .085 & 2.620 & $\mathbf{. 0 0 9}$ \\
& Intelekt & -.041 & -1.200 & .230 \\
& Savesnost & .300 & 9.179 & $\mathbf{. 0 0 0}$ \\
& & & & \\
& Pol & -.109 & -3.326 & $\mathbf{. 0 0 1}$ \\
& Obrazovanje & .068 & 2.123 & $\mathbf{. 0 3 4}$ \\
& Prijatnost & .163 & 4.844 & $\mathbf{. 0 0 0}$ \\
& Emocionalna stabilnost & -.006 & -.173 & .863 \\
& Ekstraverzija & .078 & 2.389 & $\mathbf{. 0 1 7}$ \\
& Intelekt & -.038 & -1.095 & .274 \\
& Savesnost & .291 & 8.836 & $\mathbf{. 0 0 0}$ \\
& Zadovoljstvo životom & .067 & 2.053 & $\mathbf{. 0 4 0}$ \\
\hline
\end{tabular}

Napomena. Muški pol je kodiran sa „,1”, dok je ženski pol kodiran sa „„”. 


\section{DISKUSIJA}

Osnovni cilj ovog istraživanja bilo je ispitivanje relacija između pet velikih dimenzija ličnosti i zadovoljstva životom, sa jedne strane, i važnih pozitivnih i negativnih životnih događaja, sa druge strane.

Prva hipoteza je potvrđena - emocionalna stabilnost (kao suprotan pol dimenzije neuroticizma (Goldberg, 1999) značajno predviđa negativne događaje u negativnom smeru. Ovakav nalaz u skladu je sa prethodnim istraživanjima (Fergusson \& Horwood, 1987; Headey \& Wearing, 1989; Magnus et al., 1993; Gomez et al., 2009; Kandler et al., 2012). Osobe koje su emocionalno stabilne generalno reaguju pozitivnije na različite stimuluse i situacije u odnosu na osobe koje imaju povišen neuroticizam. Posledično, takve osobe zapažaju i izveštavaju o manjem broju negativnih događaja koji nastaju usled negativnih stimulusa (ili uslova). Alternativno objašnjenje jeste da ljudi koji doživljavaju manje negativnih emocija kreiraju i manje negativnih relacija sa svojim okruženjem, što vodi ka doživljavanju manje negativnih događaja (Magnus et al., 1993; Leist et al., 2010).

Druga hipoteza je takođe potvrđena - ekstraverzija značajno i u pozitivnom smeru predviđa pozitivne životne događaje, što je u skladu sa rezultatima prethodnih istraživanja (Magnus et al., 1993; Gomez et al., 2009; Kandler et al., 2012). Ekstravertnije osobe doživljavaju više pozitivnih životnih događaja upravo zbog socijabilne komponente ove dimenzije: ovakve osobe češće ulaze u pozitivne interakcije sa drugim ljudima i aktivno tragaju za pozitivnim događajima i situacijama, koje za njih nose pozitivno potkrepljenje. Slično objašnjenje daju i Magnus i saradnici (Magnus et al., 1993), koji zapažaju da osobe sa povišenom ekstraverzijom aktivnije tragaju za pozitivnim događajima, usled izraženije potrebe za nagradom.

Naredni važan nalaz ovog istraživanja jeste da dimenzija prijatnost predviđa i pozitivne i negativne važne životne događaje, u pozitivnom smeru. Osobe sa povišenjem na ovoj dimenziji jesu prema drugim ljudima tople $u$ komunikaciji, prijemčive, spremne na kompromise i generalno fleksibilne. Na primer, prijatan komunikacioni stil prema kolegama na poslu, u zavisnosti od karakteristika situacije, može rezultovati i napredovanjem na poslu - pozitivan događaj, ali takođe i prihvatanjem prevelikog broja radnih zadataka i zaduženja ili zanemarivanjem vlastitih potreba - negativan događaj. Ovakav nalaz otvara niz pitanja za naredna istraživanja, o potencijalnim mehanizmima delovanja prijatnosti na važne životne događaje.

Savesnost se pokazala kao značajan prediktor važnih pozitivnih životnih događaja. Važni pozitivni životni događaji u sklopu ovog upitnika vezani su 
prvenstveno za uspehe, na poslovnom i privatnom planu, ali takođe $\mathrm{i}$ sa samokontrolom, što su indikatori savesnosti. Osobe koje su savesne, dobro organizovane, sa visokom samokontrolom, češće će doživljavati pozitivne životne događaje vezane za poslovne uspehe, uspehe u obrazovanju, uspehe unutar porodice i u kontekstu potomstva, kao i značajne pozitivne unutrašnje promene.

Ovakav odnos osobina ličnosti i životnih događaja mogao bi se objasniti interakcionistički - čini se da postoji dvosmerna veza između osobina i događaja. Izlaganje različitim situacijama nalazi se pod uticajem osobina ličnosti, jer osobe tragaju za specifičnim situacijama i okruženjima kao rezultat svojih genetskih predispozicija (Magnus et al., 1993; Kandler et al., 2010). Životni događaji nisu samo spoljašnji - oni imaju i svoju unutrašnju komponentu koja je u snažnoj relaciji sa konstelacijom osobina ličnosti osobe. Većina događaja zapravo je unutrašnje pokrenuta ili izazvana (Leist et al., 2010; Vázquez et al., 2015), pa se zato jedan isti događaj često dešava istim ljudima. Čini se da su osobine koje oblikuju takve uslove u našoj kulturi neuroticizam, ekstraverzija, prijatnost i savesnost.

Rezultati ukazuju na to da zadovoljstvo životom predviđa pozitivno pozitivne životne događaje i negativno negativne životne događaje, što je u skladu sa prethodnim istraživanjem tog odnosa (Lybomirsky et al., 2005; Leist et al., 2010; Luhman et al., 2013). Osobe koje su zadovoljne svojim životom su proaktivne, pozitivne, socijalno aktivnije, samim tim tragaju za više pozitivnih iskustava i pozitivnih interpersonalnih transakcija. Posledično, one doživljavaju i veći broj takvih događaja (Lybomirsky et al., 2005). Sa druge strane, moguće je da se nezadovoljstvo životom javlja kao prediktor važnih negativnih životnih događaja usled mehanizma kao što je anticipacija tih događaja (Luhman et al., 2013). Osoba predviđa da se mogu desiti negativni životni događaji u budućnosti i samim tim joj opada zadovoljstvo životom. Kada je reč o relacijama kontrolnih (sociodemografskih) varijabli i važnih životnih događaja, najvažniji nalaz ovog istraživanja jeste da su ove relacije veoma niskog intenziteta. Drugim rečima, intenzitet ovih relacija ukazuje na zaključak da sociodemografske karakteristike nisu od suštinskog značaja za razumevanja pojave važnih životnih događaja, što je u skladu sa nalazima prethodnih studija (Heady \& Wearing, 1989).

Sistematizacija nalaza ovog istraživanja pruža dublji uvid u strukturu relacija između navedenih fenomena. Sociodefmografska obeležja ostvaruju najslabije relacije sa oba tipa važnih životnih događaja. Pozitivni događaji su u snažnijoj relaciji sa osobinama ličnosti, dok su negativni događaji u snažnijoj relaciji sa zadovoljstvom životom. Iako je struktura relacija različita, kumulativan efekat ovih relacija ostvaruje nisku povezanost (oko 15\% objašnjene varijanse) i sa 
pozitivnim i sa negativnim važnim životnim događajima. Naredna istraživanja bi trebala da ukažu na preciznije implikacije strukturalnih mehanizama koji stoji u zajedničoj osnovi navedenih fenomena.

Neke od ograničenja ove studije, a samim tim i smernica za naredna istraživanja, odnose se na ispitivanje prediktivne moći osobina ličnosti upotrebom faceta/dimenzija nižeg reda. Moguće je da npr. visoka gregarnost, faceta ekstraverzije ili nisko samopouzdanje, faceta neuroticizma, mogu bolje i u većem stepenu objasniti vezu ovih dimenzija sa životnim događajima. Jedan od ciljeva narednih istraživanja jeste i proveriti da li postoje razlike $u$ mehanizmima uticaja dispozicionih činilaca na važne životne događaje, ako se posmatraju i kratkoročni i dugoročni efekti zasebno.

Bojan Branovački, Selka Sadiković, Milan Oljača

\section{RELATIONS BETWEEN IMPORTANT LIFE EVENTS, PERSONALITY TRAITS AND LIFE SATISFACTION}

\section{Summary}

Aim of this study was to examine relations between personality traits, life satisfaction and important positive and negative life events. Most of the previous research was aimed at assessing the influence of Neuroticism and Extraversion on important life events, while the question of influence of other personality traits and life satisfaction has garnered significantly less attention. Sample consisted of 933 participants. Sample was uniform in respect to gender $(50.1 \%$ female), and average age of the sample was 34.95 years $(\mathrm{SD}=$ 12.87) ranging from 19 to 69 years. Big 5 Personality traits were measured using IPIP BIG 5 questionnaire and SWLS was used to measure cognitive component of life satisfaction (subjective wellbeing). In order to assess life events new questionnaire was created. Scale of important life events consists of two subscales meant to measure frequency of important positive and negative life events throughout the lifetime. Both positive and negative life events are represented by 30 events in the scale (60 in total) which include aspects of material, partner, emotional, health, work and existential life domains. In order to assess relations between personality dimensions, life satisfaction and important life events two multiple regression analyses were conducted. Important negative life events have significant positive relation with Agreeableness, and negative relations with Emotional stability and life satisfaction. Important positive life events have significant positive relations with Agreeableness, Extraversion and life satisfaction. Gender and Education also were significant predictors of positive events indicating that men and higher educated participants experience more positive life events through lifetime. These results are preliminary and in need of further verification. Conclusions of this research are that both personality traits and life satisfaction have important influence on important life events. The results mainly give 
support to previous results and indicate that life events should not be perceived as independent of personality. This research provides several new insights about the relations between personality traits, life satisfaction and life events, but it is also important to note that more research is needed in order to fully understand the complex nature of these phenomena.

Key words: life events, personality traits, life satisfaction, Scale of important life events

\section{LITERATURA}

Alea, N., Ali, S., \& Marcano, B. (2014). The Bumps in Trinidadian Life: Reminiscence Bumps for Positive and Negative Life Events. Applied Cognitive Psychology, 28(2), 174 - 184. doi: 10.1002/acp.2975

Bleidorn, W., Hopwood, C. J., \& Lucas, R. E. (2018). Life Events and Personality Trait Change. Journal of Personality, 86(1), 83-96. doi: 10.1111/jopy. 12286

Cleland, C., Kearns, A., Tannahill, C., \& Ellaway, A. (2016). The impact of life events on adult physical and mental health and well-being: longitudinal analysis using the GoWell health and well-being survey. BMC Research Notes, 9. https://doi.org/10.1186/s13104-016-2278-x

Diener, E., Emmons, R.A., Larsen, R.J., \& Griffin, S. (1985). The satisfaction with life scale. doi: 10.1207/s15327752jpa4901_13

Diener, E., Lucas, R. E., \& Scollon, C. N. (2006). Beyond the hedonic treadmill: revising the adaptation theory of well-being. The American Psychologist, 61(4), 305-314. doi: 10.1037/0003-066X.61.4.305

Farmer, A. S., \& Kashdan, T. B. (2012). Social Anxiety and Emotion Regulation in Daily Life: Spillover Effects on Positive and Negative Social Events. Cognitive Behaviour Therapy, 41(2), 152 - 162. doi: 10.1080/ 16506073.2012.666561

Fergusson, D. M., \& Horwood, L. J. (1987). Vulnerability to life events exposure. Psychological Medicine, 17(3), 739-749. doi: 10.1017/ S0033291700025976

Garcia, D., \& Sikstrom, S. (2013). Quantifying the Semantic Representations of Adolescents' Memories of Positive and Negative Life Events. Journal of Happiness Studies, 14(4), 1309 - 1323. doi: 10.1007/s10902-012-9385-8

Goldberg, L.R. (1999). A broad-bandwidth, public domain, personality inventory measuring the lower-level facets of several five-factor models. In I. Mervielde, I. Deary, F. De Fruyt, F., \& F Ostendorf (Eds.), Personality psychology in Europe. Tilburg, The Netherlands: Tilburg University Press. 
Gomez, V., Krings, F., Bangerter, A., \& Grob, A. (2009). The influence of personality and life events on subjective well-being from a life span perspective. Journal of Research in Personality, 43(3), 345-354. doi:10.1016/j.jrp.2008.12.014

Headey, B., \& Wearing, A. (1989). Personality, life events, and subjective wellbeing: Toward a dynamic equilibrium model. Journal of Personality and Social Psychology, 57, 731-739. Preuzeto sa http://psycnet.apa.org/buy/1990-00988-001

Jeronimus, B. F., Ormel, J., Aleman, A., Penninx, B. W. J. H., \& Riese, H. (2013). Negative and positive life events are associated with small but lasting change in neuroticism. Psychological Medicine, 43(11), 2403 - 2415. doi: 10.1017/S0033291713000159

Kandler, C., Riemann, R., Spinath, F. M., \& Angleitner, A. (2010). Sources of variance in personality facets: a multiple-rater twin study of self-peer, peerpeer, and self-self (dis)agreement. Journal of Personality, 78(5), 15651594. doi:10.1111/j.1467-6494.2010.00661.x

Kandler, C., Bleidorn, W., Riemann, R., Angleitner, A., \& Spinath, F. M. (2012). Life events as environmental States and genetic traits and the role of personality: a longitudinal twin study. Behavior Genetics, 42(1), 57-72. doi: 10.1007/s10519-011-9491-0

Leist, A. K., Ferring, D., \& Filipp, S.-H. (2010). Remembering positive and negative life events: Associations with future time perspective and functions of autobiographical memory. GeroPsych: The Journal of Gerontopsychology and Geriatric Psychiatry, 23(3), 137-147. doi:10.1024/1662-9647/a000017

Luhmann, M., Lucas, R. E., Eid, M., \& Diener, E. (2013). The Prospective Effect of Life Satisfaction on Life Events. Social Psychological and Personality Science, 4(1), 39-45. doi: 10.1177/1948550612440105

Lykken, D., \& Tellegen, A. (1996). Happiness is a stochastic phenomenon. Psychological Science, 7(3), 186-189. doi:10.1111/j.14679280.1996.tb00355.x

Lyubomirsky, S., King, L., \& Diener, E. (2005). The benefits of frequent positive affect: does happiness lead to success? Psychological Bulletin, 131(6), 803855. doi: 10.1037/0033-2909.131.6.803

Lyubomirsky, S., Sheldon, K. M., \& Schkade, D. (2005). Pursuing happiness: The architecture of sustainable change. Review of General Psychology, 9(2), 111-131. doi: 10.1037/1089-2680.9.2.111 
Luhmann, M., Lucas, R. E., Eid, M., \& Diener, E. (2013). The Prospective Effect of Life Satisfaction on Life Events. Social Psychological and Personality Science, 4(1), 39-45. doi: 10.1177/1948550612440105

Magnus, K., Diener, E., Fujita, F., \& Pavot, W. (1993). Extraversion and neuroticism as predictors of objective life events: A longitudinal analysis. Journal of Personality and Social Psychology, 65, 1046-1053. Preuzeto sa http://psycnet.apa.org/buy/1994-29643-001

Mukaka, M. M. (2012). A guide to appropriate use of correlation coefficient in medical research. Malawi Medical Journal, 24(3), 69-71. Preuzeto sa https://www.ncbi.nlm.nih.gov/pmc/articles/PMC3576830/

Orth, U., \& Robins, R. W. (2014). The development of self-esteem. Current Directions in Psychological Science, 23, 381-387. doi: 10.1177/0963721414547414

Pickles, A., \& Rutter, M. (1991). Statistical and conceptual models of „turning points" in developmental processes. In D. Magnusson, L. R. Bergman, G. Rudinger, \& B. T€orestad (Eds.), Problems and methods in longitudinal research: Stability and change (pp. 133-165). Cambridge: Cambridge University Press.

Spinhoven, P., Elzinga, B. M., Hovens, J. G. F. M. Roelofs, K., \& Penninx, B. W. J. H. (2011). Positive and negative life events and personality traits in predicting course of depression and anxiety. Acta Psychiatrica Scandinavica, 124, 462-473. doi: 10.1111/j.1600-0447.2011.01753.x

Tabachnick, B. G., and Fidell, L. S. (2013). Using Multivariate Statistics, 6th ed. Boston: Pearson.

Vázquez, J. J., Panadero, S., \& Martín, R. M. (2015). Regional and national differences in stressful life events: The role of cultural factors, economic development, and gender. The American Journal of Orthopsychiatry, 85(4), 392-396. doi:10.1037/ort0000029 


\section{DODATAK}

\section{Dodatak A.}

Spisak pozitivnih važnih životnih događaja.

\section{Rb. Događaj}

1. Doživeo sam uspeh u formalnom obrazovanju (dobio sam

1. diplomu/stipendiju/nagradu, položio važan ispit, studijski boravak).

2. Moja religijska shvatanja su se značajno promenila.

3. Postao sam finansijski samostalan (finansijski nezavisan od drugih).

4. Polagao sam vozački ispit.

5. Otišao sam na neobično (netipično ili egzotično) putovanje.

6. Prisustvovao sam religijskom okupljanju.

7. Preselio sam se u inostranstvo.

8. Vratio sam se u rodni grad/državu rođenja, nakon dugo vremena.

9. Izgradio sam/kupio sam kuću/stan.

10. Saznala sam da sam trudna/saznao sam da je moja partnerka trudna.

11. Zasnovao sam bračni odnos.

12. Zaljubio sam se.

13. Počeo sam ozbiljnu emotivnu vezu.

14. Rodilo se dete sa kojim sam u srodstvu (brat, sestra, unuk, unuka...).

15. Meni bliska osoba se vratila iz inostranstva.

16. Promenio sam društvo (grupe prijatelja).

17. Dogodio mi se veliki poslovni uspeh.

18. Doživeo sam uspeh u svom hobiju.

19. Promenio sam radno mesto/posao.

20. Dobio sam posao.

21. Pokrenuo sam svoj privatani posao/biznis.

22. Rodilo mi se dete.

23. Moje dete se oženilo/udalo.

24. Prestao sam da konzumiram cigarete.

25. Otišao sam kod psihologa ili na psihoterapiju.

26. Moje zdravstveno stanje se znatno popravilo.

27. Prekinuo sam da konzumiram alkohol i/ili psihoaktivne supstance.

28. Doživeo sam značajan uvid ili značajnu "unutrašnju" promenu.

29. Finansijska situacija mi se značajno poboljšala.

30. Sam sam otišao na putovanje/odmor. 


\section{Dodatak $B$.}

Spisak negativnih važnih životnih događaja.

\section{Rb. Događaj}

1. Izgubio sam vrednu imovinu.

2. Doživeo sam stambeni problem (npr. bilo je neizvesno gde ću živeti u bližoj

2. budućnosti).

3. Doživeo sam pljačku ili krađu moje ili porodične imovine.

4. Moj kućni ljubimac se izgubio ili je uginuo.

5. Doživeo sam neuspeh u formalnom obrazovanju (neuspeh pri upisu, napuštanje škole ili fakulteta, pad na ispitu i sl.).

6. Imala sam komplikaciju tokom ili nakon trudnoće. /Moja partnerka je imala

6. komplikacije tokom ili nakon trudnoće.

7. Partner me je prevario.

8. Razočarao sam se u emotivnu vezu/brak.

9. Saznao sam da član porodice/partner ima ozbiljniju/težu bolest.

10. Ja ili moja porodica sam se našao u lošoj finansijskoj situaciji.

11. Moji roditelji su se razveli.

12. Doživeo sam smrt bliskog prijatelja.

13. Meni bliska osoba ili član porodice je otišao na izdržavanje zatvorske kazne.

14. Jako sam se razočarao u posao ili radno mesto.

15. Dobio sam otkaz.

16. Prisustvovao sam ratnim dešavanjima.

17. Moja porodica i ja smo doživeli izbeglištvo.

18. Mom detetu je dijagnostikovana ozbiljnija bolest.

19. Bio sam ozbiljno zabrinut za vlastitu bezbednost/fizičko zdravlje.

20. Meni bliska osoba je izvršila ili pokušala samoubistvo.

21. Saznao sam da imam neku ozbiljniju/tešku bolest (npr. rak, hepatitis i sl.).

22. Brinuo sam se da je ugrožena bezbednost člana moje porodice.

23. Meni bliska osoba je teško povređena ( prelom ruke, saobraćajna nezgoda i $\mathrm{sl})$.

24. Saznao sam da blizak prijatelj ima ozbiljniju/težu bolest.

25. Konzumirao sam alkohol ili psihoaktivne supstance u prevelikoj količini.

26. Doživeo sam nervni slom.

27. Neko od meni bliskih prijatelja ili članova porodice je pokušao ili izvšio samoubistvo.

28. Doživeo sam smrt člana porodice.

29. Imao sam neprijatno seksualno iskustvo.

30. Neko od mojih prijatelja ili članova porodice je dobio otkaz. 